\title{
THE ANTIBACTERIAL ACTIVITY OF FRACTIONS OF ETHYL ACETATE GARCINIA LATISSIMA MIQ. STEM BARK EXTRACTS AGAINST BACILLUS SUBTILIS AND PSEUDOMONAS AERUGINOSA
}

\author{
NENENG SITI SILFI AMBARWATI ${ }^{1,2}$, AMARILA MALIK ${ }^{3 *}$, ELFIRA AMALIA DEBORAH ${ }^{3}$, CAKRA HAGAI ARPATI SM ${ }^{3}$, \\ MA'ULFI HANIF ${ }^{3}$, BERNA ELYA ${ }^{2}$, MUHAMMAD HANAFI ${ }^{4}$
}

${ }^{1}$ Department of Family Well-Being, Faculty of Engineering, Universitas Negeri Jakarta, Jakarta, Indonesia, ${ }^{2}$ Department of Pharmacognosy and Phytochemistry, Faculty of Pharmacy, Universitas Indonesia, UI Campus Depok, Depok 16424, Indonesia. ${ }^{3}$ Department of Microbiology and Biotechnology of Pharmacy, Faculty of Pharmacy, Universitas Indonesia, UI Campus Depok, Depok 16424, Indonesia. ${ }^{4}$ Research Centre for Chemistry, Indonesian Institute of Sciences (LIPI), Tangerang, Indonesia.

Email: amarila.malik@ui.ac.id

Received: 21 April 2017, Revised and Accepted: 13 July 2017

ABSTRACT

Objective: This research focuses on the antibacterial activities of fractions of ethyl acetate Garcinia latissima Miq. extracts against Bacillus subtilis and Pseudomonas aeruginosa.

Methods: For each bacteria, the values of the inhibitory zone diameter were determined using paper discs method, while the minimum inhibitory concentration (MIC) was determined by microdilution and antibacterial assay was determined by bioautography. Fractionation was carried out using gradient elution with silica gel column as stationary phase successively increasing the separation according to the polarity (using combination of eluents; n-hexane, ethyl acetate, and methanol).

Results: To determine the diameter of the inhibitory zone for each fraction, the fractions were diluted with dimethyl sulfoxide until the concentration of each fraction was $20,000 \mathrm{ppm}$. The results showed that fraction B had no inhibitory zone against B. subtilis. The inhibitory zone diameters of fractions A, C, D, E, F, and G against B. subtilis were 7.600 $\pm 0.000,6.767 \pm 0.202,7.950 \pm 0.477,7.883 \pm 0.901$, and $9.233 \pm 0.231 \mathrm{~mm}$, respectively. Only Fraction G had an inhibition zone diameter of $7.200 \pm 0.173 \mathrm{~mm}$ against $P$. aeruginosa. The active fractions were tested by contact bioautography using silica gel (60 GF254) plate and hexane:chloroform (2:3) as mobile phase for Fractions A, C, D, E, and F and chloroform:ethyl acetate (4:1) as mobile phase for Fraction G. The thin layer chromatography plates were observed under the ultraviolet light at wavelengths of 254 and $366 \mathrm{~nm}$, while the others plate (using in contact bioautography) placing on agar medium that had been inoculated with the bacteria, so the compounds could be diffuse to the medium. The active compound will appeared inhibitory zones in agar medium. The determination of the MIC values using microdilution with methylthiazol tetrazolium salt showed that fractions of the ethyl acetate extracts of $G$. latissima Miq. stem bark inhibited the growth of $B$. subtilis more actively than P. aeruginosa. The highest activity of the fractions against B. subtilis was shown by fraction G, which had a MIC value of 78.125 ppm, followed by fractions F (156.25 ppm), E (312.5 ppm), D (625 ppm), C (1250 ppm), B (2500 ppm), and A (5000 ppm). The highest activity of the fractions against $P$. aeruginosa was Fraction G (5000 ppm), while the MIC values of other fractions were $>5000 \mathrm{ppm}$.

Conclusion: Further investigations should be conducted to obtain the new antibacterial compounds in fractions of ethyl acetate extract of $G$. latissima Miq. stem bark that effective to inhibit the growth of B. subtilis and P. aeruginosa.

Keywords: Antibacterial activities, Garcinia latissima Miq., Ethyl acetate fractions, Stem bark, Bacillus subtilis, Pseudomonas aeruginosa.

(C) 2017 The Authors. Published by Innovare AcademicSciences PvtLtd.This is an open access article under the CC BY license (http://creativecommons. org/licenses/by/4. 0/) DOI: http://dx.doi.org/10.22159/ajpcr.2017.v10s5.23100

\section{INTRODUCTION}

Medicinal plants contain thousands of active substances that can be used for therapeutic purposes. These substances are a precursor for the synthesis of drugs that are useful and safe for human health [1]. With recent population growth, concerns about health problems have led to the need for the development of natural antimicrobials to control microbial disease. Antimicrobial activity found in plant extracts is associated with some secondary metabolites contained there in Garcinia latissima Miq. is a plant belonging to the Clusiaceae tribe that can be found on Seram Island in the Maluku Islands and Papua Island [2]. This plant, which has been cultivated in the Bogor Botanical Gardens of West Java, G. latissima Miq. and which is better known as Dolo magota (Maluku), is commonly used to treat wounds [2]. Ethyl acetate extracts of G. latissima Miq. stem bark have been found to contain flavonoids and alkaloids [3]. Specifically, the stem bark from G. latissima Miq. which grows in the Central Province of Papua New Guinea, has been found to contain latisxanton-A, latisxanton-B, latisxanton-C, and latisxanton-D compounds belonging to the pyrano xanthone group [4].
The ethyl acetate extract of G. latissima Miq. stem bark (2\%) in dimethyl sulfoxide (DMSO) has demonstrated antibacterial activity against Bacillus subtilis and Pseudomonas aeruginosa [3]. Therefore, it is necessary to investigate the activity of the ethyl acetate extract fractions of G. latissima Miq. further. Liquid-solid column chromatography, which requires column packaging with multiple adsorbents such as silica gel, can be used for the stationary phase. The sample will then be eluted using a solvent, and the force of gravity pushes the solvent downward. Adsorption will cease when a balance is reached between the mobile phase and the stationary phase [5]. Motion phase solvents with different polarities, ranging from n-hexane to methanol, are used in low-pressure column chromatography [6]. Thus, fractions will be obtained that increase polarity.

\section{METHODS}

The ethyl acetate extracts of $G$. latissima Miq. stem bark that were used in this study existed from previous research conducted at the Phytochemical Laboratory of the Faculty of Pharmacy in the University 
of Indonesia [3]. For fractionation, $25 \mathrm{~g}$ of the extract and silica gel 60 (S) were used in the silent phase. Successive solvents were used (n-hexane, ethyl acetate, and methanol) with the polarity increasing according to gradient [7]. The fractions collected and tested using thin layer chromatography (TLC) for the separation profile. For each fraction that has similar separation chromatogram profile mixed into one fraction.

The bacteria used in this experiment were B. subtilis (ATCC 6633) and $P$. aeruginosa (ATCC 27853). These bacteria were taken from a collection at the Microbiology Laboratory of the Faculty of Pharmacy (University of Indonesia). The first antibacterial test was conducted to determine the diameter of the inhibitory zone. Warm antibiotic media that were inoculated by the bacteria test were poured over the agar medium for $B$. subtilis and the cetrimide agar medium for compacted $P$. aeruginosa. This test used fractions with a $20,000 \mathrm{ppm}$ concentration of DMSO. Each fraction was dropped on a paper disc. Once each fraction dried, it was placed on top of the prepared media. Then, the fractions were incubated at $37^{\circ} \mathrm{C}$ for $24 \mathrm{hrs}$ for B. subtilis and at $28^{\circ} \mathrm{C}$ for $48 \mathrm{hrs}$ for $P$. aeruginosa [8].

Fractions that had inhibitory zones were further tested using contact bioautography. The 20,000-ppm fraction solution $(10 \mu \mathrm{L})$ was eluted on a TLC plate using a suitable eluent; then, it was dried slowly and visualized under ultraviolet light at wavelengths of $254 \mathrm{~nm}$ and $366 \mathrm{~nm}$, and the Rf values were measured [9]. After each fraction was dried, it was attached to the agar layer and left for approximately $1 \mathrm{hr}$ to allow for diffusion of the compound content. Then, the TLC plate was removed, and the Petri dish was incubated at $37^{\circ} \mathrm{C}$ for $24 \mathrm{hrs}$ for both Staphylococcus aureus and B. subtilis and at $28^{\circ} \mathrm{C}$ for $48 \mathrm{hrs}$ for P. aeruginosa [10].

Fractions minimum inhibitory concentration (MIC) test was conducted using a microdilution method. Fractions from a DMSO solution of $20,000 \mathrm{ppm}$ were diluted using bacterial medium or broth to obtain the following concentrations: $10,000 \mathrm{ppm}, 5000 \mathrm{ppm}, 2500 \mathrm{ppm}$, $1250 \mathrm{ppm}, 625 \mathrm{ppm}, 312.5 \mathrm{ppm}$, and $156.25 \mathrm{ppm}$. Each $50-\mu \mathrm{L}$ fraction solution was added to $50 \mu \mathrm{L}$ of inoculum, which contained bacteria at a concentration of 106 colony-forming unit per mL. Tests for each well of the microplate obtained fraction concentrations of 5000, 2500, 1250, $625,312.5,156.25$, and $78.125 \mathrm{ppm}$. Each concentration was placed in 3 wells because the test was done in triplicate. The positive control for B. subtilis was erythromycin, while the positive control for P. aeruginosa and S. aureus was gentamycin.

The microplate was then incubated at $37^{\circ} \mathrm{C}$ for $24 \mathrm{hrs}$. For P. aeruginosa, the incubation was carried out at a temperature of $28^{\circ} \mathrm{C}$ for $48 \mathrm{hrs}$. After incubation, $0.6 \mathrm{mg} / \mathrm{mL}$ of 3-(4,5-dimethylthiazol-2-yl)-2,5diphenyltetrazolium bromide (MTT) solution was added to $10-\mu \mathrm{L}$ sterile aquifers [11] and then incubated for 20 minutes [12]. The observations were conducted by visually checking the presence or absence of discoloration as the presence of bacterial growth is characterized by a change of color from light yellow to purple or pink. The lowest concentration of non-discolored wells is the MIC [13].

\section{RESULTS AND DISCUSSION}

Fractionation in column chromatography used $100 \%$ n-hexane solvent, which was then added to the ethyl acetate by reducing the n-hexane so that the polarity increased by a gradient to $100 \%$ ethyl acetate. Subsequently, methanol was added, and the ethyl acetate was reduced until the solution reached $100 \%$ methanol. The chromatographic results of this column were stored in a $100 \mathrm{~mL}$ bottle. Each fraction in the bottle was tested with TLC, and the fraction which has similar chromatogram pattern was combined. From the fractionation results, Fraction G had the highest percentage (60.8268\%). Fraction G was also the most polarized, followed by Fractions C $(9.9968 \%)$, D (8.8129\%), A (7.5140\%), F (7.1154\%), E (3.9652\%), and B (1.7659\%) (Table 1).

The test to determine the diameter of the inhibitory zone was done triplicate with a fraction concentration at $20,000 \mathrm{ppm}$. Based on the results of this test, which used the diffusion method on paper discs, the fractions that could indicate the diameter of the inhibitory zone toward B. subtilis were G, F, D, E, A, and C, from the bigger diameter of the fraction to smaller diameter consecutively (Table 2). In contrast, the only fraction that could provide the diameter of the inhibitory zone toward P. aeruginosa was fraction G.

With the results of the above test to determine whether there was a compound contained in the fraction that could indicate the diameter of the inhibitory zone, a bioautographic test was performed using a 20,000-ppm concentration of test solution (10 $\mu \mathrm{L})$ (Figs. 1 and 2).

The next antibacterial test was the MIC test, which uses an MTT indicator-to detect microbial growth. This dehydrogenase reagent indicator (tetrazolium salt) works based on the reduction reaction of yellow tetrazolium salt to purple formazan crystals by the action of dehydrogenase enzymes on the mitochondria of the cell (Fig. 3) [14].

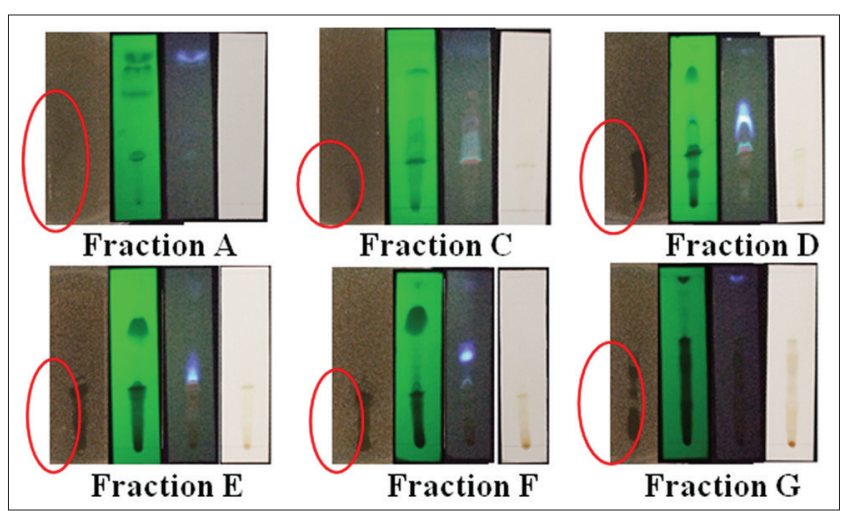

Fig. 1: Bioautography results of active fraction of ethyl acetate extracts of Garcinia latissima Miq. stem bark against $B$. subtilis using n-hexane:chloroform (2:3) as eluent for Fractions A, B, C, D, E, and F. For the Fraction G, the chloroform:ethyl acetate (4:1) was used as eluent

Table 1: Fractionation of G. latissima Miq. ethyl acetate extracts

\begin{tabular}{llll}
\hline Fraction & Bottle number & Fraction weight (g) & Fraction (\%) \\
\hline A & $1-4$ & 0.7578 & 7.5140 \\
B & $5-9$ & 0.1784 & 1.7689 \\
C & $10-12$ & 1.0082 & 9.9968 \\
D & $13-15$ & 0.8888 & 8.8129 \\
E & $22-33$ & 0.3999 & 3.9652 \\
F & $34-60$ & 0.7176 & 7.1154 \\
G & $61-223$ & 6.1345 & 60.8268 \\
\hline
\end{tabular}

Total fraction weight 10.0852. G. latissima: Garcinia latissima

Table 2: The inhibitory zone diameters results of the ethyl acetate fractions of $G$. latissima against $B$. subtilis and P. aeruginosa

\begin{tabular}{lll}
\hline Fraction & $\begin{array}{l}\text { Diameter of the inhibitory } \\
\text { zone }(\mathbf{m m}) \text { against bacteria }\end{array}$ \\
\cline { 2 - 3 } & B. subtilis & P. aeruginosa \\
\hline A & $7.600 \pm 0.000$ & 0 \\
B & 0 & 0 \\
C & $6.767 \pm 0.202$ & 0 \\
D & $7.950 \pm 0.477$ & 0 \\
E & $7.883 \pm 0.901$ & 0 \\
F & $9.233 \pm 0.231$ & 0 \\
G & $9.300 \pm 0.173$ & $7.200 \pm 0.173$ \\
Standard antibiotics & $23.58 \pm 0.988$ & $17.92 \pm 0.549$ \\
\hline
\end{tabular}

G. latissima: Garcinia latissima, B. subtilis: Bacillus subtilis,

P. aeruginosa: Pseudomonas aeruginosa 
The succinic dehydrogenase produced by the mitochondria of living cells and contained within these microbes can actively convert the tetrazolium (MTT) salt into purple formazan [10].

From the MIC test results (Table 3), the MIC value obtained from Fraction G was 78.13 ppm, so Fraction G has strong antibacterial activity against $B$. subtilis. Fractions $\mathrm{E}$ and $\mathrm{F}$ have MIC values of 312.5 and $156.25 \mathrm{ppm}$, respectively, and medium antibacterial activity toward B. subtilis. Fraction D has weak antibacterial activity toward B. subtilis (625 ppm). This is consistent with reference to the MIC values of $<100 \mathrm{ppm}, 100-500 \mathrm{ppm}, 500-1000 \mathrm{ppm}$, and $>1000 \mathrm{ppm}$ indicate strong, moderate, weak, and inactive/absent antimicrobial activity, respectively [15]. The antimicrobial activity of these test fractions was compared with standard antibiotics: Erythromycin for B. subtilis and gentamicin for $P$. aeruginosa.

The seven fractions tested showed different inhibitory effects. The results showed that the most susceptible bacteria to Fraction $G$ were

Table 3: Results of the MIC of the ethyl acetate fraction of G. Iatissima Miq. stem bark (ppm)

\begin{tabular}{lll}
\hline Fractions & B. subtilis & P. aeruginosa \\
\hline A & 5000 & $>5000$ \\
B & 2500 & $>5000$ \\
C & 1250 & $>5000$ \\
D & 625 & $>5000$ \\
E & 312.5 & $>5000$ \\
F & 156.25 & $>5000$ \\
G & 78.13 & 5000 \\
Standard antibiotics & 25 & 0.39 \\
\hline
\end{tabular}

MIC: Minimum inhibitory concentration, G. latissima: Garcinia latissima, B. subtilis: Bacillus subtilis, P. aeruginosa: Pseudomonas aeruginosa

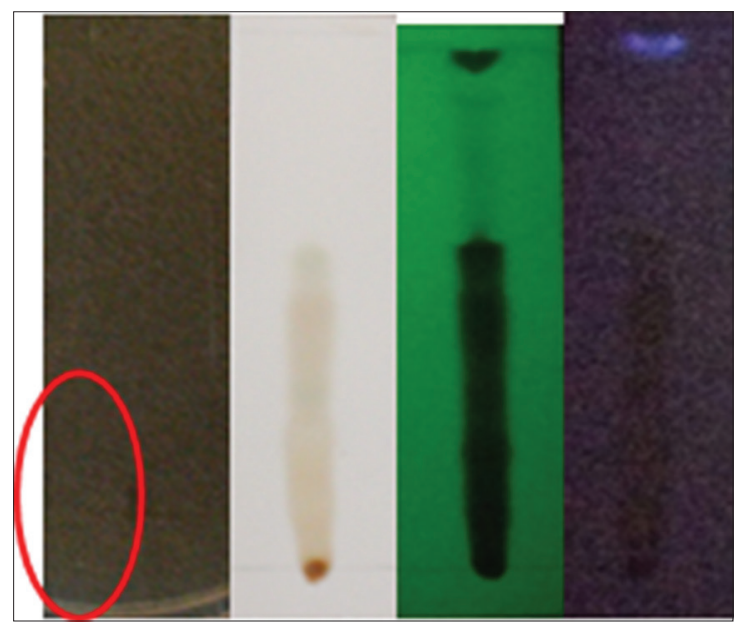

Fig. 2: Bioautography results of the active fraction of ethyl acetate extract of Garcinia latissima Miq. stem bark against Pseudomonas aeruginosa using chloroform:ethyl acetate (4:1) as eluent

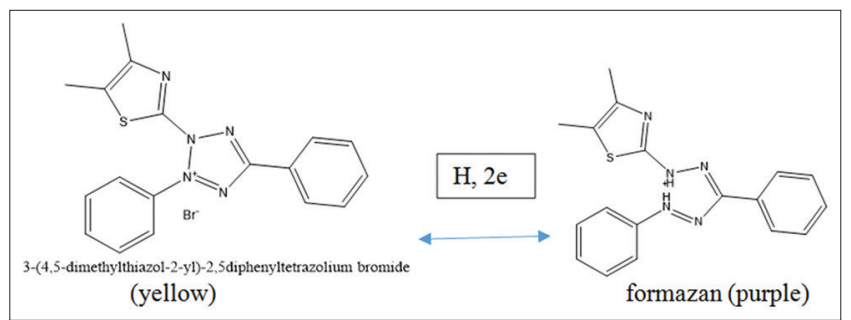

Fig. 3: The reaction of tetrazolium salt reduction by enzyme dehydrogenase
B. subtilis. Gram-positive bacteria (such as B. subtilis) are more susceptible to active fractions than Gram-negative bacteria (such as P. aeruginosa). This has been demonstrated by the susceptibility of microbes to various fractions reported in literature that Gram-positive bacteria more susceptibility than Gram-negative bacteria [15]. One explanation is that the cell walls of Gram-positive bacteria are less complex than Gramnegative bacteria and do not have selectivity for large molecules [16]. The walls of these cells are composed of a thick layer of mucopeptides (peptidoglycan) (40-50\% of the bacterial body weight), while the cell walls of Gram-negative bacteria contain layers of fat and peptidoglycan (20\% and $5-20 \%$ of the body weight, respectively) [17].

\section{CONCLUSION}

From the fractionation of ethyl acetate extract of $G$. latissima Miq. stem bark, Fraction $G$ has the largest percentage of total weight fraction (60.8268\%). Fraction $\mathrm{G}$ also has the greatest diameter of inhibitory zone compare to the other fractions against $B$. subtilis and P. aeruginosa using paper disc method. From the results of bioautography test, the active fractions showed the inhibitory zone on the agar medium. The MIC test results showed that Fraction G has the strongest antibacterial activity against $B$. subtilis and $P$. aeruginosa. Therefore, further research is needed to isolate and obtain the new active compound from the active fraction of ethyl acetate extract of G. latissima Miq. stem bark.

\section{ACKNOWLEDGMENTS}

The authors gratefully acknowledge the receipt of the PITTA grant (2017) from the University of Indonesia, for the financial support of this work.

\section{REFERENCES}

1. Li JJ. Top Drugs-History, Pharmacology, and Synthesis. New York: Oxford University Press; 2014.

2. Eisai P. Medicinal Herb Index in Indonesia. $2^{\text {nd }}$ ed. Jakarta: Eisai Indonesia; 1995.

3. Ambarwati NS, Elya B, Malik A, Hanafi M. Evaluation of antimicrobial activities of Garcinia latissima Miq. Stem bark extract. J Young Pharm 2017;9(1):118-21.

4. Ito C, Miyamoto Y, Nakayama M, Kawai Y, Rao KS, Furukawa H. A novel depsidone and some new xanthones from Garcinia species. Chem Pharm Bull 1997;45(9):133-40.

5. Ahuja S. Separation science and technology. Chromatography and Separation Science. California: Elsevier Science; 2003

6. Reid RG, Sarker SD. Isolation of natural products by low-pressure column chromatography. In: Sarker SD, Nahar L, editors. Natural Product Isolation Methods and Protocols. New York: Humana Press; 2012.

7. Martins S, Amorim EL, Sobrinho TJ, Saraiva AM, Pisciottano MN, Aguilar $\mathrm{CN}$, et al. Antibacterial activity of crude methanolic extract and fractions obtained from Larrea tridentata leaves. Ind Crops Prod 2013;41:306-11.

8. Kochuthressia KP, Britto SJ, Jaseentha MO, Raphael R. In vitro antimicrobial evaluation of Kaempferia galanga L. Rhizome extract. Am J Biotechnol Mol Sci 2012;2(1):1-5.

9. Sarker SD, Latif Z, Gray AI. Natural Products Isolation. $2^{\text {nd }}$ ed. New Jersey: Humana Press; 2006.

10. Dewanjee S, Gangopadhyay M, Bhattacharya N, Khanra R, Dua TK. Bioautography and its scope in the field of natural product chemistry. J Pharm Anal 2015;5(2):75-84

11. Biloa Messi B, Ho R, Meli Lannang A, Cressend D, Perron K, Nkengfack AE, et al. Isolation and biological activity of compounds from Garcinia preussii. Pharm Biol 2014;52(6):706-11.

12. Grare M, Fontanay S, Cornil C, Finance C, Duval RE. Tetrazolium salts for MIC determination in microplates: Why? Which salt to select? How? J Microbiol Methods 2008;75(1):156-9.

13. Zubair M, Rizwan K, Rasool N, Ahmed V. Antimicrobial potential of various extract and fractions of leaves of Solanum nigrum. Int J Phytomed 2011;3(1):63-7.

14. Suwantong O, Pankongadisak P, Deachathai S, Supaphol P. The potential of electrospun poly(L-lactic acid) fiber mats containing a crude Garcinia dulcis extract for use as wound dressings. Chiang Mai J Sci 2013;40(3):517-33. 
15. Fernandes MR, Dias AL, Carvalho RR, Souza CR, Oliveira WP. Antioxidant and antimicrobial activities of Psidium guajava L. Spray dried extracts. Ind Crops Prod 2014;60:39-44.

16. Ohadoma SC, Natuanya IV, Amazu LU, Okolo CE. Antimicrobial activity of the leaf extract and fractions of Lupinus arboreus. J Med
Plant Res 2014;8(8):386-91.

17. Ibrahim A, Ahmad I, Narsa AC, Sastyarina Y. Effect of antimicrobial preparation of skin ointment based on ethyl acetate sungkai leaf extract (Peronema canencens Jack.) Against bacterial infectious pathogen burn. J Trop Pharm Chem 2013;2(3):125-31. 